$98: 1636$

<症例報告 $>$

急性肝炎を経過後, 無黄疸性の胆道酵素上昇が持続した

肝腫大を伴 血糖不安定型糖尿病性腎症の 1 透析例

$\begin{array}{lllll}\text { 武田 和久* } & \text { 大森 } & \text { 浩之** } & \text { 小川 勝士** 芳野 健*** } \\ \text { 植杉成一郎** } & \text { 大森 } & \text { 晶彦** } & \text { 小坂 㾸夫** } & \end{array}$

要 旨：糖尿病性腎症にて血液透析中の 36 歳の女性が，血糖調節の悪化とともに著明な肝腫大 をきたし，経過中肝不全で発症後無黄疸性高アルカリフォスファターゼ (ALP) 血症を伴う慢 性肝炎 (非 A 非 B 型) に移行し，腎不全の増悪により死亡した 1 剖検例を報告した。本症例の 空腹時血糖値は, $20 \sim 48$ 単位のインスリン使用時に 100 以下から $1,000 \mathrm{mg} / \mathrm{d} l$ を越学る変動を示 し, 肝は右肋弓下 7 横指に達した. 血清 ALP 活性は肝炎併発啳 GOT, GPT の変動と一致して 増減し77.8K-AUに達したが, 血清ビリルビン值は $1.0 \mathrm{mg} / \mathrm{d} l$ 以下であった. ALP以外に LAP, $\gamma$-GTP 活性, 紷コレステロール值も上昇し, Slow-migrating HDLが出現するなど胆汁 らっ滞の所見を示した。組織学的には糖原の蓄積による肝の腫大が考えられたが胆汁うっ滞の 所見はなく，慢性肝炎に付随した胆汁らっ沮の特殊型としての無黄疸性胆道醅素上昇症の存在 が示唆された。

索引用語 :

高フルカリフォスファターゼ血症

肝糖原蓄積 糖尿病性腎症

慢性肝炎 血液透析

はじめに

糖尿病性腎症に対し血液透析中の患者が，血桾調節 の悪化とともに著明な肝腫大をきたし，さらに肝不全 にて発症後無黄疸性高フルカリフォスファターゼ (ALP) 血症 (肝型) を伴う慢性肝炎に移行し， 1 年余 の経過で腎不全の増悪により死亡した。剖検時に胆管 系の閉塞所見はなく肝糖原量の増加を認めた。本症例 の高 ALP 血症と肝の糖原蓄積に関して若干の検討を 加党たので報告する。

患者：36歳女性. 主婦.

$$
\text { 症例 }
$$

主訴：嗜眠傾向と見当識障害.

既往歴：20歳の頃糖尿病を指摘され，以後インスリ ン治療を受けた。昭和56年, 蛋白尿, 高血压が出現。 昭和58年 1 月精查目的で当附属病院入院時には血糖の 調節は良好, $\mathrm{HbA}_{1}$ は8.8\%, 肝も触知しなかったが腎 不全の状態にあり，同年 7 月から血液透析を開始，以 後外来で週 3 日施行した。 この頃から血糖の調整が困

*香川大学保健管理センター

**重井医学研究所附属病院

*** 重井病院

<受付日62年 3 月 30 日 $>$
難となり， $\mathrm{HbA}_{1}$ は $11.3 \%$ と上昇，空腹時血糖も 1,000 $\mathrm{mg} / \mathrm{d} l$ k及ぶ不安定型糖尿病の経過をとった。昭和59 年12月まで, 月 2 回の定期肝機能検查で, ALPを含め, 異常なし．血清コレステロールと中性脂肪は共に正常 值から $500 \mathrm{mg} / \mathrm{d} l$ にわたる変動を示し, 冬から春にか けて高い傾向にあった。

家族歴：特記すべきことなし。

現病歴：昭和60年 1 月 5 日の検査で初めて, GOT $110 \mathrm{KU}, \mathrm{GPT} 90 \mathrm{KU}, \mathrm{ALP} 14.2 \mathrm{~K} \cdot \mathrm{AU}$ 之肝機能異常 に気付き，肝を肋弓下に 3 横指触知した，自覚的には 感冒様症状が約 1 週間持続した. 1 月 8 日透析中㖺眠 傾向あり，1月10日には見当識の障害が出現した，同 日の肝機能検查で GOT $5,730 \mathrm{KU}$, GPT $3,810 \mathrm{KU}$, LDH 11,300WU, ALP 34.3K-AU と異常高値を認め, 血中 $\mathrm{NH}_{3}$ む101 $\mu \mathrm{g} / \mathrm{d} l$ と上昇を示したが，血糖值は 97 $\mathrm{mg} / \mathrm{d} l$ と正常であった。血浆了ミノダラム(いずれる 単位は $\mathrm{nmol} / \mathrm{m} l)$ では, バリン 175.7, インロイシン 62.0, ロイシン 108.5 と正常であったが, メチオニン 56.9, チロシン172.1, フェニールアラニン284.4と上 昇し, BCAA/AAA 比は 0.76 と低値を示した。肝不全 の猃断にて翌11日当附属病院に入院した.

入院時現症：体格, 栄盖中等, 体温 $36.8^{\circ} \mathrm{C}$, 脈拍78/ 
分, 整, 血压130/68mmHg. 意識レベルは低下し（III 〜IV度の昏睡),その間に興奮状態を繰り返した。呼吸 は不整，瞳孔は軽度散大，左右不同なく，対光反射は 鈍, 深部反射は左右之も減弱, 病的反射, 䯣膜刺激症 状, 振顴はなかった。顔面は蒼白, 浮腫状, 眼䀫結膜 に負血なく，眼球結膜に黄疸を認めなかった。心肺に 打聴診上異常なく, 肺肝境界は第 5 肋骨, 肝を右鎖骨 中線上で肋弓下 4 横指触知し, 辺縁は鋭, 表面平滑, 弾性硬, 脾, 腎は触知せず, 腹水も認めなかった。

入院時検查成績：Table 1 に示すよ5に，著明な䝯 血, 白血球增多, 血小板减少, 及び, 尿素窒素, クレ アチニンの上昇に加えて, GOT, GPT, $\mathrm{LDH}_{5}$ の著明 な増加と凝固系の障害が認められた。また，同時に肝 性 $\mathrm{ALP}\left(\mathrm{ALP}_{2}\right), \mathrm{LAP}$ も高値を示したが $\gamma$-GTPは軽 度上昇に留まり, 血清ビリルビン值は正常範囲内に あった. HBsAg, HBsAb, HbcAb, HA 抗体はいず れも陰性, 血液型は $\mathrm{A}$ 型であった。

入院時体重は $47.2 \mathrm{~kg}$ ，身長 $160 \mathrm{~cm}$, 胸部 X 線写真で 心胸比は66.3\%と堌大し，肺門陰影の拡大を認めた。 超音波断層所見では，肝両葉の著明な腫大を認めたが，
内部ェコーは均一で, 胆管の抬張もなく, 脾腫と腹水 の貯留を軽度に認めた。

入院後経過：グルカゴン・インスリン療法（グルカ ゴン $1 \mathrm{mg}$, インスリン10U/日), アミノレバン $200 \mathrm{~m} l /$ 日の投与に加光，DHP-1(クラレ)を用いた吸着と血 液透析を 4 回, 1 日1,970から $3,100 \mathrm{~m} l$ の血浆交換 (Plasmacure, クラレを使用)を計 6 回施行し, 凝固機 能の改善とともに1月13日より意識レベルの正常化を みた。血清トランスフミナーゼの異常も急速に改善し たが, その後再び変動を繰り返し, ALP 活性の上昇を 伴い, 䀒腫す再び著明となった。これらの変化と関連 を有すると思われる使用薬剤はなく，蛋痒感も訴えな かった，その後血液透析に拈ける患者の協力が十分得

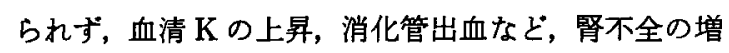
悪をきたし昭和61年 4 月 7 日に死亡した。. 透析回数は 入院時までの202回と併せ, 計401回で, 輸血量は入院 後計24単位であった。

入院後の検查成績：Fig. 1 亿示寸如く, ALP 活性は GOT 及びGPT 活性の上昇に一致して増加し，ALP/ GOT (GPT) 比は, 初回上りも第 2 回以後の変動時に

Table 1 Laboratory data on admission.

\begin{tabular}{|c|c|c|c|c|c|}
\hline \multicolumn{2}{|l|}{ Hematological tests: } & \multicolumn{2}{|l|}{ Blood chemistry: } & \multirow{2}{*}{$\begin{array}{l}\text { Cholin-Ease } \\
\text { CPK }\end{array}$} & \multirow{2}{*}{$\begin{array}{l}239 \mathrm{mU} / \mathrm{m} l \\
334 \mathrm{IU} / l^{\cdot}\end{array}$} \\
\hline RBC & $04 \times 10^{4} / \mathrm{mm}^{3}$ & $\mathrm{pH}$ & 7.328 & & \\
\hline $\mathrm{Hb}$ & $6.0 \mathrm{~g} / \mathrm{d} l$ & $\mathrm{Na}$ & $135 \mathrm{mEq} / l$ & BB & $1 \%$ \\
\hline $\mathrm{Ht}$ & $20 \%$ & $\mathrm{~K}$ & $5.9 \mathrm{mEq} / l$ & MB & $2 \%$ \\
\hline WBC & $16,300 / \mathrm{mm}^{3}$ & $\mathrm{Ca}$ & $4.5 \mathrm{mEq} / l$ & MM & $95 \%$ \\
\hline Metamyelo. & $4 \%$ & $\mathrm{Cl}$ & $98 \mathrm{mEq} / \mathrm{l}$ & Alb & $2 \%$ \\
\hline St. & $25 \%$ & $\mathrm{HCO}_{3}$ & $21.6 \mathrm{mEq} / l$ & Total protein & $6.2 \mathrm{~g} / \mathrm{d} l$ \\
\hline Seg. & $50 \%$ & Osm.pr. & $323 \mathrm{mOsm} / l$ & Alb & $64.0 \%$ \\
\hline Ly. & $12 \%$ & Urea-N & $79.6 \mathrm{mg} / \mathrm{d} l$ & $\alpha 1$ & $6.3 \%$ \\
\hline Eo. & $5 \%$ & Creatinine & $7.7 \mathrm{mg} / \mathrm{d} l$ & $\alpha 2$ & $8.5 \%$ \\
\hline $\mathrm{Ba}$. & $1 \%$ & Uric acid & $12.6 \mathrm{mg} / \mathrm{d} l$ & $\beta$ & $7.6 \%$ \\
\hline Mo. & $3 \%$ & $\mathrm{NH}_{3}$ & $70 \mu \mathrm{g} / \mathrm{d} l$ & $\gamma$ & $13.3 \%$ \\
\hline \multirow{2}{*}{\multicolumn{2}{|c|}{$\begin{array}{c}\text { Platelet } 3.8 \times 10^{4} / \mathrm{mm}^{3} \\
\text { Urinalysis }\left(1 / 30 /{ }^{3} 85\right):\end{array}$}} & Fasting glucose & $210 \mathrm{mg} / \mathrm{d} l$ & IgG & $1,021 \mathrm{mg} / \mathrm{d} l$ \\
\hline & & GOT & $5,460 \mathrm{KU}$ & $\operatorname{Ig} A$ & $254 \mathrm{mg} / \mathrm{d} l$ \\
\hline \multicolumn{2}{|l|}{ Reaction } & GPT & $4,040 \mathrm{KU}$ & IgM & $57 \mathrm{mg} / \mathrm{d} l$ \\
\hline \multicolumn{2}{|l|}{ Protein } & LDH & $10,600 \mathrm{WU}$ & ZTT & $5.1 \mathrm{KU}$ \\
\hline \multicolumn{2}{|l|}{ Sugar } & 1 & $7 \%$ & TTT & $3.4 \mathrm{KU}$ \\
\hline \multicolumn{2}{|l|}{ Urobilinogen } & 2 & $12 \%$ & CRP & 世 \\
\hline \multicolumn{2}{|l|}{ Bilirubin } & 3 & $9 \%$ & $\mathrm{C}_{3}\left(1 / 16 /{ }^{\prime} 85\right)$ & $70 \mathrm{mg} / \mathrm{d} l$ \\
\hline \multicolumn{2}{|l|}{$\mathrm{Hb}$} & 4 & $21 \%$ & $\mathrm{CH}_{50}\left(1 / 16 /{ }^{\prime} 85\right)$ & $37.3 \mathrm{U}$ \\
\hline Sed. RBC & $1-3 / 10 \mathrm{~F}$ & 5 & $51 \%$ & Prothrombin time & $21.5 \mathrm{sec}$ \\
\hline WBC & $1-2 / 1 \mathrm{~F}$ & ALP & $37.9 \mathrm{~K} \cdot \mathrm{AU}$ & Hepaplastin test & $34.3 \%$ \\
\hline Ep. & $1-2 / 5 \mathrm{~F}$ & 1 & $6 \%$ & Fibrinogen & $150 \mathrm{mg} / \mathrm{d} l$ \\
\hline Granul. cast & $3-10 / 1 F$ & 2 & $69 \%$ & FDP & $40 \mu \mathrm{g} / \mathrm{ml}$ \\
\hline \multicolumn{2}{|l|}{ Stool $(1 / 15 / ' 85):$} & 3 & $25 \%$ & Total-chol. & $166 \mathrm{mg} / \mathrm{d} l$ \\
\hline \multirow[t]{2}{*}{ Occult blood } & $(+)$ & LAP & 858 G-RU & Total-bilirubin & $0.9 \mathrm{mg} / \mathrm{d} l$ \\
\hline & & $\gamma$-GPT & $76 \mathrm{mU} / \mathrm{ml}$ & Direct-bilirubin & $0.4 \mathrm{mg} / \mathrm{d} l$ \\
\hline
\end{tabular}




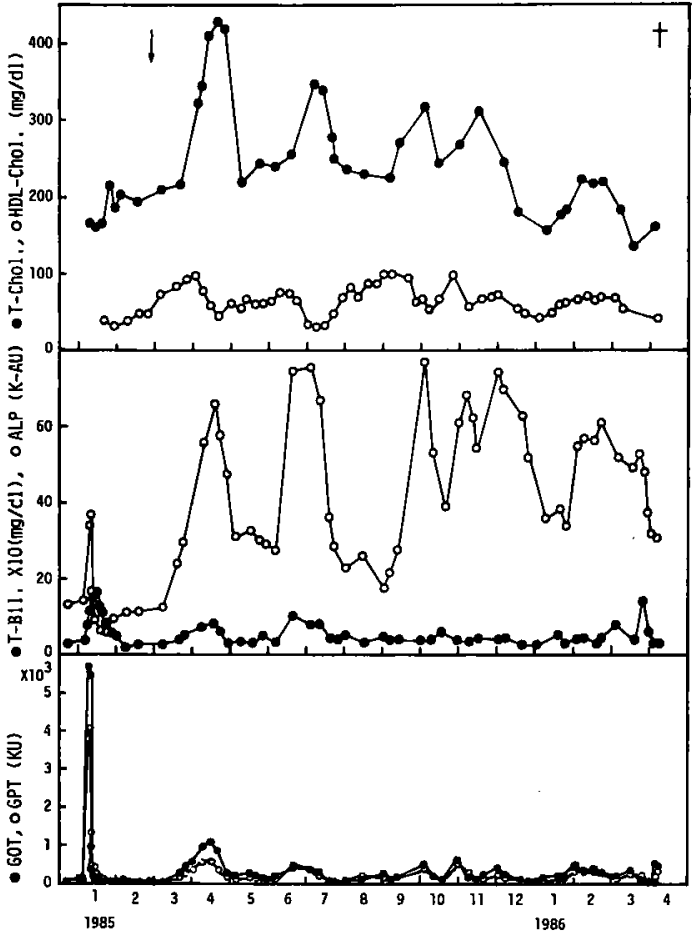

Fig. 1 Serum levels of GOT, GPT, alkaline phosphatase, total bilirubin, total cholesterol and HDL-cholesterol during the course of illness.

より大であった．総ビリルビン値は ALP 活性の增加 とともに上昇傾向を示したが, $1.0 \mathrm{mg} / \mathrm{d} l$ 以下に留 まった．総コレステロール値はALP 活性のピークと 一致して増加し，HDL コレステロール值は全般的に 高値であったが，総コレステロールの増加時には逆に 一時的に低下した. 空腹時血糖は Fig. 2 に示す如く， $1,220 \mathrm{cal}$ （蛋白 $47 \mathrm{~g}$, 脂肪 $30 \mathrm{~g}$, 含水炭素 $190 \mathrm{~g}$ ) の食事 とインスリン（主にアクトラピッド）1日量24３6単 位，時に48単位の 4 分割投与において低血糖症状を伴 $5100 \mathrm{mg} / \mathrm{d} l$ 以下から $1,000 \mathrm{mg} / \mathrm{d} l$ に及ぶ短期間内の 増減を絽り返し，血糖の調節が困難であった，血糖値 及び投与インスリン量と肝尰の程度との間の関係は明 かでなかったが，死亡前 2 週間頃から食事摄取量が著 明に減少し，肝腫も 3 横指程度にまで縮小した。胸 比の変動と肝尰の程度との間に特別の関連は見られな かった。

臨床経過中のその他の肝機能検查成績を Table 2 に示した，入院時の検查異常值はほほほ 1 力月以内に正

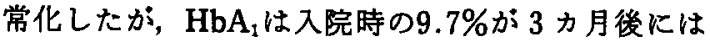
$15.2 \%$ となり，その間血糖の高值が存在したことを示

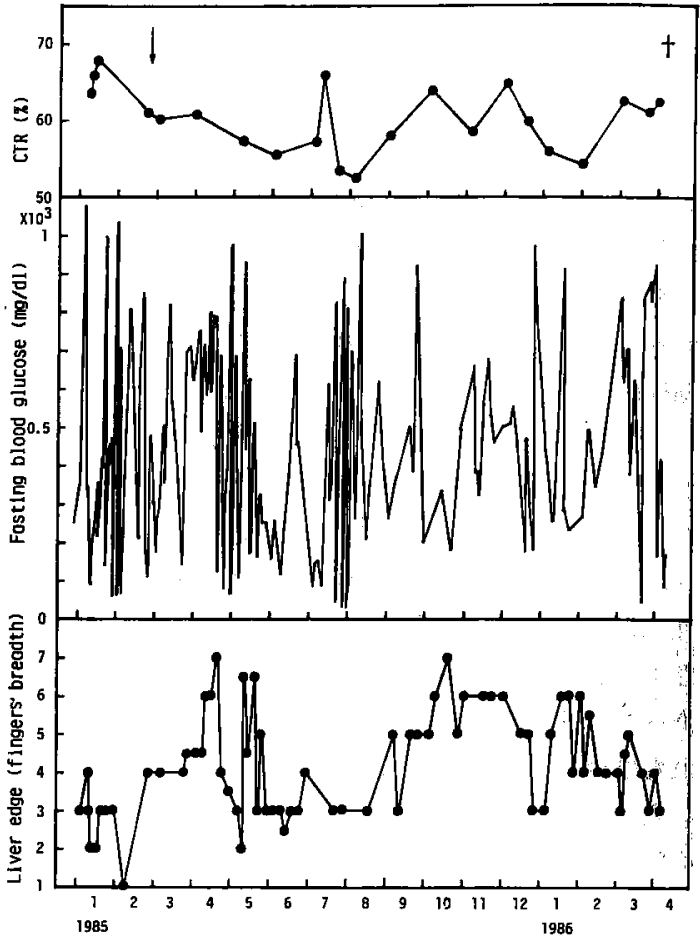

Fig. 2 Fasting blood glucose level, cardiothoracic ratio and liver size below the right costal margin during the course of illness.

Table 2 Laboratory data during the course of illness.

\begin{tabular}{|c|c|}
\hline $1 / 16 / ' 85$ & $\begin{array}{l}\mathrm{HbA}_{1} 9.7 \%, \mathrm{Fe} 93 \mu \mathrm{g} / \mathrm{d} l, \mathrm{Cu} 100 \mu \mathrm{g} / \mathrm{d} l, \mathrm{AFP}<3 \mathrm{ng} / \\
\mathrm{m} l, \mathrm{AMA}<\times 10\end{array}$ \\
\hline $1 / 21 / 85$ & $\begin{array}{l}\mathrm{AFP}<3 \mathrm{ng} / \mathrm{m} l, \mathrm{CPK} 64 \mathrm{IU} / l, \mathrm{Mb} 180 \mathrm{ng} / \mathrm{m} l \text {, } \\
\text { CMV }<\times 4, \mathrm{~EB} \text { VCA-IgG } \times 160 \text {, other anti-EB virus } \\
\text { antibodies }(-)\end{array}$ \\
\hline $2 / 2 / 85$ & Triglycerides $222 \mathrm{mg} / \mathrm{d} l$ \\
\hline $2 / 5 / 85$ & $\mathrm{Fe} 83 \mu \mathrm{g} / \mathrm{d} l$ \\
\hline $3 / 25 / ' 85$ & CPK $39 \mathrm{IU} / l$ \\
\hline /'85 & $\mathrm{Mb} 100 \mathrm{n}$ \\
\hline $4 / 17 / ' 85$ & $\begin{array}{l}\text { ALP } 65.8 \mathrm{~K} \text {-AU(1 } 10 \%, 2 \text { 77\%, } 3 \quad 10 \%, 40 \%, 5 \\
3 \%, \gamma \text {-GTP } 625 \mathrm{mU} / \mathrm{ml}, \text { LAP 523G-RU }\end{array}$ \\
\hline $4 / 30 / \cdot 85$ & $\mathrm{Fe} 188 \mu \mathrm{g} / \mathrm{d} l, \mathrm{Cu} 142 \mu / \mathrm{d} l$ \\
\hline $6 / 4 / 85$ & $\begin{array}{l}\mathrm{Ib} 8.3 \mathrm{ng} / \mathrm{ml}, \mathrm{Fe} 188 \mathrm{ug} / \mathrm{d} l \text {, UIBC } 20 \\
\mathrm{ng} / \mathrm{m} l\end{array}$ \\
\hline $11 / 8 / ' 85$ & $\begin{array}{l}\text { ALP } 68.1 \mathrm{~K}-\mathrm{AUU}(1 \quad 10 \%, 2 \quad 78 \%, 3 \quad 12 \%, 4 \quad 0 \%, 5 \\
0 \%), \gamma \cdot \mathrm{GTP} 383 \mathrm{mU} / \mathrm{m} l, \mathrm{LAP} 307 \mathrm{IU} / l, \mathrm{Fe} 114 \mu \mathrm{g} / \mathrm{d} l \text {, } \\
\text { UBIC } 111 \mu \mathrm{g} / \mathrm{d} l\end{array}$ \\
\hline $11 / 2$ & ICG 1.0 \\
\hline $12 / 16 / ' 85$ & $\begin{array}{l}\text { Total-chol. } 179 \mathrm{mg} / \mathrm{d} l, \text { HDL-chol. } 54.4 \mathrm{mg} / \mathrm{d} l, \text { tri- } \\
\text { glyceride } 193 \mathrm{mg} / \mathrm{d} l, \beta \text {-lipoprotein } 395 \mathrm{mg} / \mathrm{d} l \text {, lipo- } \\
\text { protein electrophoresis } \alpha \text { with tailing } 52 \% \text {, pre- } \beta \\
15 \%, \beta 33 \%) L P \cdot X(-) \text {, CEA } 1.2 \mathrm{ng} / \mathrm{m} l, \mathrm{CA} 19-951 \\
\mathrm{U} / \mathrm{m} l \text {, glycocholate } 140 \mathrm{ng} / \mathrm{d} l\end{array}$ \\
\hline $4 / 7 / 86$ & $\begin{array}{l}\text { Total bile acids } 22.1 \mu \mathrm{mol} / l, \mathrm{Cu} 164 \mu \mathrm{g} / \mathrm{d} l \text {, ALP(1 } \\
5 \%, 2 \quad 77 \%, 3 \quad 18 \%, 40 \%, 50 \%), \mathrm{CA} 19-954 \\
\mathrm{U} / \mathrm{m} l, \mathrm{CEA} 2 . \mathrm{Ing} / \mathrm{m} l, \mathrm{AMA}<\times 10, \mathrm{ASMA}<\times 20 \\
\text { EB VCA-IgG } \times 80 \text {, other anti-EB virus antibodies } \\
(-) \text {, HSI IgG } \times 640 \text {, HSI IgM }<\times 10 \text {, HAAb, } \\
\text { HBsAg, HbsAb, HBeAg, HBeAb, HBcAb(-) }\end{array}$ \\
\hline
\end{tabular}


した，高 ALP 血症は，肝型アインザイム $\left(\mathrm{ALP}_{2}\right)$ の 増加によるもので, 同時に, 他の胆道酵素である LAP 及び $\gamma$-GTP 活性の増加, 血清胆汁酸及び $\mathrm{Cu}$ の高值, CA19-9の上昇などを伴った. 12月の時点で総コレステ ロールは低値で LP.X す陰性, HDL コレステロール も正常レベルであったが、リポ蛋白の電気泳動で胆汁 らっ滞性の Slow-migrating HDL ${ }^{1.2)}$ ( $\alpha$-リポ蛋白の増 加とテイリング像、Fig. 3)を認めた. ICGの停滞はな かった，肝炎ウイルス関連抗原，抗体は HBcAbを含 めて陰性, CMV 抗体も陰性, EB 及び HS1ウイルス抗 体は IgGのみ陽性，抗ミトコンドリフ抗体は陰性で あった。

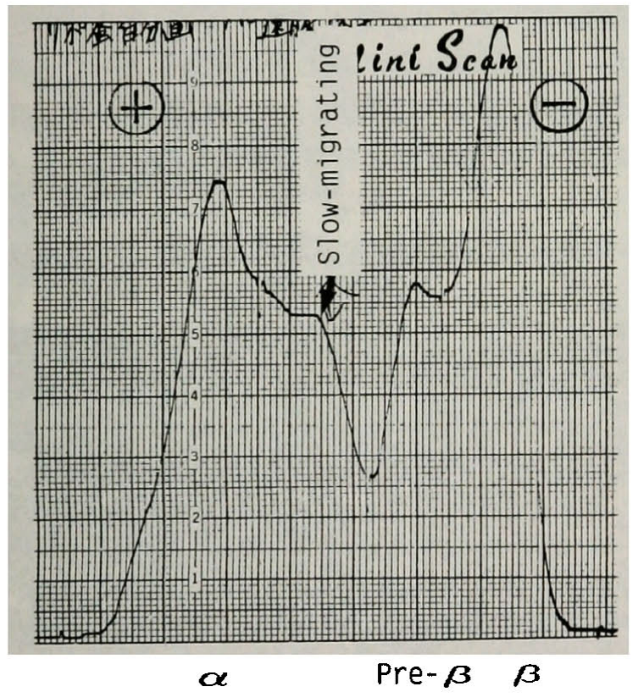

Fig. 3 An electrophoretic profile of lipoproteins on 12/16/1985 (see Table 2).

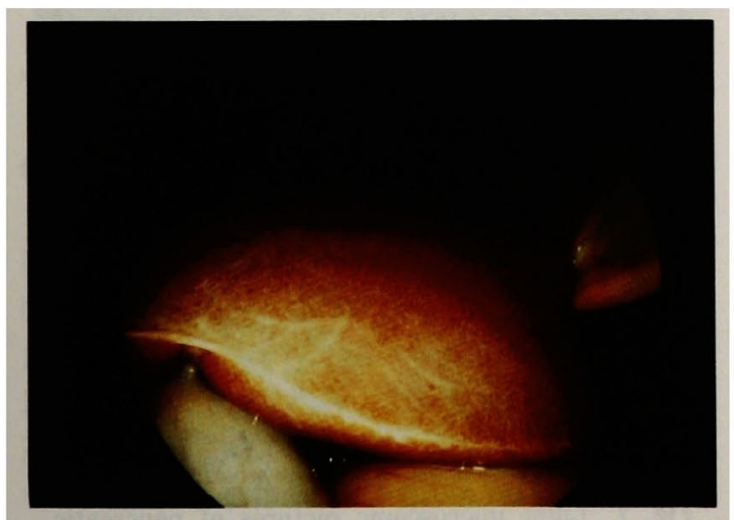

Fig. 4 A peritoneoscopic view of the right hepatic lobe.
特殊検査成績：昭和60年 2 月 4 日の CT では肝の脈 管構造が目だったが著明な萎箱はなく，CT値は70と むしろ増加を示した。

同60年 2 月 27 日に施行した腹腔鏡娭查では, 肝は両 葉とも腫大し，赤褐色調で辺縁は鈍，表面には少数の 陥凹，線維の軽度の増加および少数のリンハ小水庖を 認め，島田分類の $205 ， 1$ (9) 番の所見であった（Fig. 4).組織学的にはFig. 5aに示す如く，肝実質細胞は細 胞質の小空胞状淡明化によって腫大するものが多く， PAS 反応陽性で，㖆原核もみられた。肝細胞索の乱れ， いわゆる Spätknötchenの散見，僅かながら好酸体の 出現 (Fig. 5b) があり，アザン染色で僅かに門脈域の 拡大と小葉内へ伸びる若い結合線維の増加がみられ （Fig. 5c），急性肝炎回復期に該当する像であった。

昭和61年 4 月 7 日の血清について，七ト胎児線維芽 細胞及び羊膜上皮細胞を用いた堂光抗体間接法で細胞 骨格に対する IgG，IgA，IgM 抗体を測定したが3)、マ イクロフィラメント，細胞質微小管，中間径フィラメ

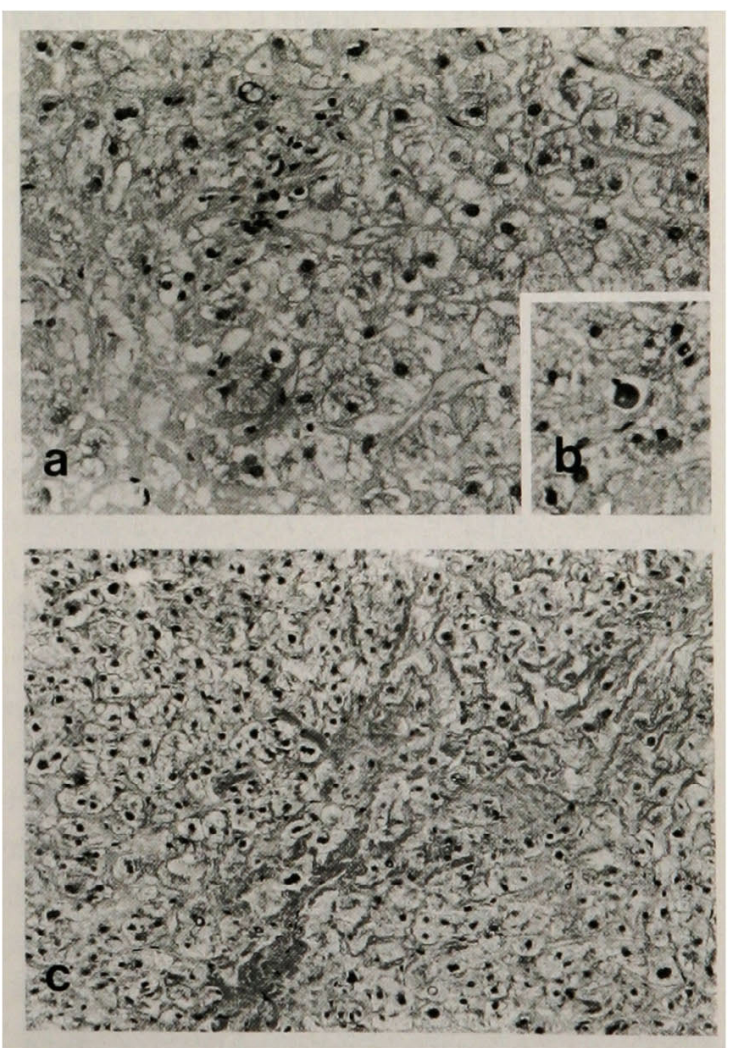

Fig. 5 Light microscopic pictures of a biopsied liver specimen. $a$ and $b$, hematoxylin-eosin stain $(\times 200)$; b, inset, showing a Councilman body ; . Azan stain $(\times 100)$. 
ントに対する抗体はいずれる陰性であった。

剖検所見：死後 1 時間で開始された剖検において， 肝は2,040g と著明に腫大し，表面は滑沢で固有の褐色 色調を呈し，胆汁らっ滞を示す緑色調はなく，肝内外 とも胆管の拡張及び炎症を示す所見はみられなかっ た. 光顕レベルにおいて, 臓器が死後比較的早期（約 3 時間半）に固定されたにしても，死亡前食事摄取に そしかった衰弱屍のフォルマリン固定肝にしては，胞 体が淡明小空胞状にゃゃ腫大した肝細胞が目立ち （Fig. 6a），これらは消化性 PAS 反応陽性で概して小 葉辺縁帯に多く分布し, 肝全体として糖原の増量が㻗 われた，肝細胞のズダン染色は陰性であった，星細胞 の活性化がみられ，へモジデリンの貪食が顕著であっ たが，らっ血を示す所見には乏しかった．門脈域内の リンパ球の浸潤は軽度で, 胆管上皮の变性も胆汁ら。 滞を示す所見もみられなかった。フザン染色で僅かに 間質結合織の増量と小葉構造の不揃いがみられたが， 偽小葉を形成する著しい改築はなく(Fig. 6b)，全体と して非活動性の慢性肝炎の組織所見であった。他臓器

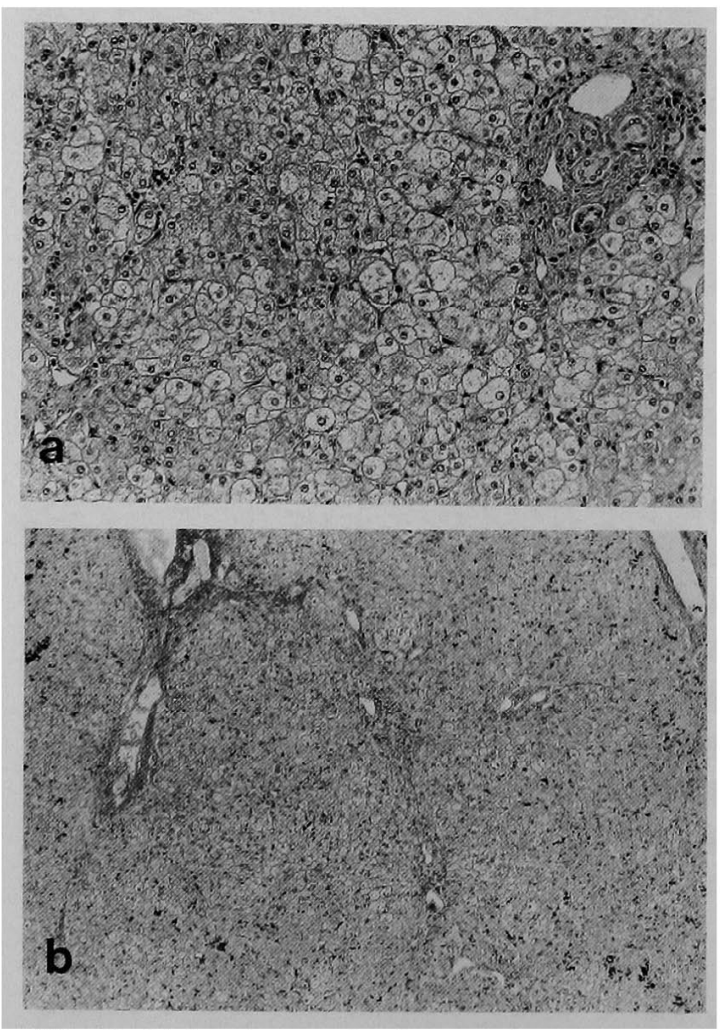

Fig. 6 Light microscopic pictures of an autopsied liver specimen. $a$, hematoxylin-eosin stain ( $x$ $100) ; b$, Azan stain $(\times 40)$.
の变化としては, 心筋の軽度の変性を伴う心肥大, 動 脈硬化症, 気管支肺炎, 脾の中等度のうっ血, 強い慢 性間質性膵炎の像とラ氏島の著明な萎縮, 消失 (Fig. 7a)，十二指腸潰瑒，系球体の強度かつ厇沉な硝子化と 慢性腎㙉炎を伴 万糖尿病性腎硬化症（Fig. 7b) が主な あのであった。

剖検時に得られた肝についての ALP 組織化学染色 では (Fig. 8)，対照例（64歳女性，肺癌，肝転移，黄 㾝なく，血清 ALP 活性も正常)の肝に比し，毛細胆管 の染色はむしろ弱く，逆に，類洞壁内皮細胞，特に星 細胞の胞体が濃染し，中心静脈や門脈域の血管内皮も 陽性で，肝実質障害の所見であっだ)。

剖検肝組織での糖原の定量(アルカリ消化,エタノー ル沈渥，フミログリコシダーゼ・へキンキナーゼ法） では，上記対照肝（死亡前の食事摃取量の減少之剖検 までの時間においても比較可能な例) の $1.4 \mathrm{mg} / \mathrm{g}$ 肝湿 重量に比し $14.8 \mathrm{mg} / \mathrm{g}$ と糖原の著増を示した。

\section{考 察}

本症例は糖尿病性腎症で血液透析により経過観察

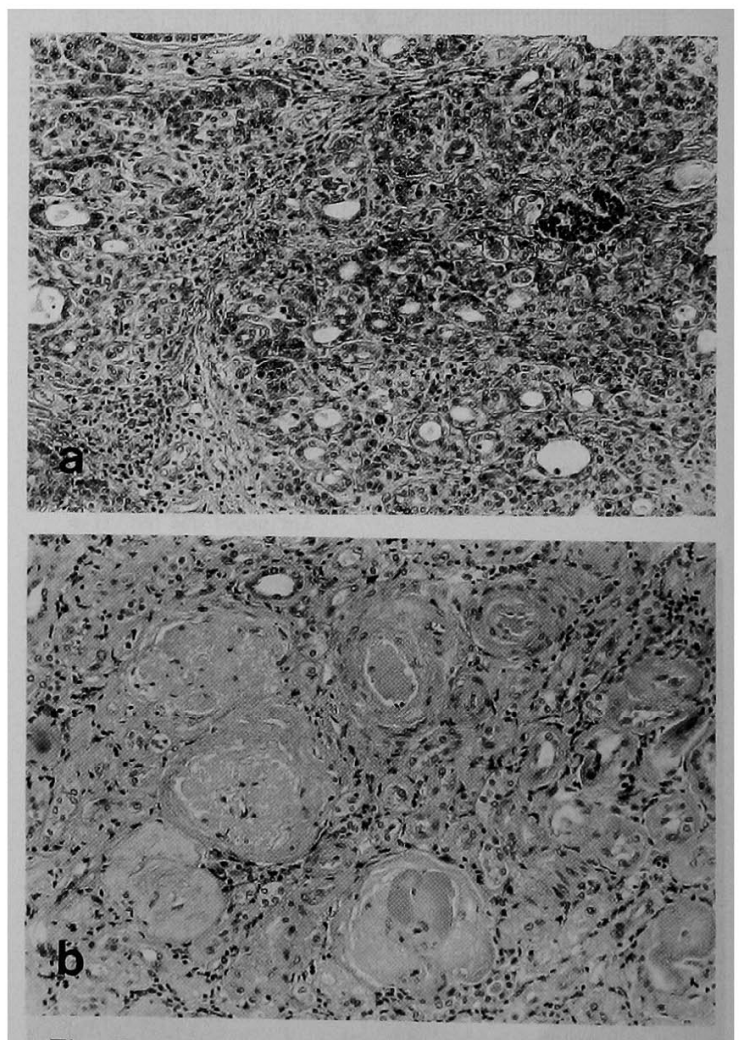

Fig. 7 Light microscopic pictures of pancreatic and kidney tissues at autopsy. Hematoxilin-eosin stain. a, pancreas $(\times 100)$; b, kidney $(\times 100)$. 


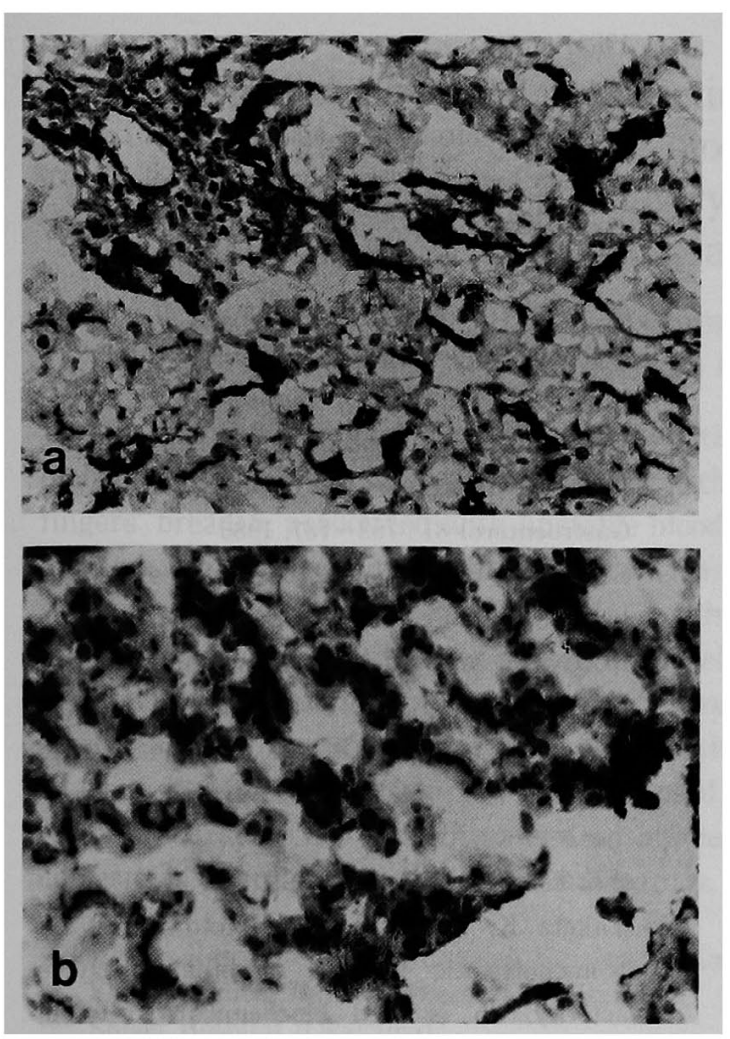

Fig. 8 Enzyme histochemical demonstration of alkaline phosphatase in autopsied liver specimens. a, the present case $(\times 200) ; b$, a control case $(\times 200)$. Sections prepared in $5 \mu \mathrm{m}$ thickness from frozen liver tissues were fixed with acetone for $10 \mathrm{~min}$ at room temperature and stained with $0.30 \mathrm{mg} / \mathrm{m} l$ TNBT and $0.16 \mathrm{mg} / \mathrm{m} l$ BCIP dissolved in a Tris-MgSO, buffer, $\mathrm{pH} \mathrm{9.2,} \mathrm{with} 0.1$ $\mathrm{m} l / \mathrm{m} l$ dimethylformamide for $20 \mathrm{~min}$ at room temperature, counterstained with $0.1 \%$ Kernechte Rot and mounted in New Entellan.

中, 急性肝不全で発症, その後非 A 非 B 型慢性肝炎と しての経過を取り, 著明な肝腫と肝型高 ALP 血症が 特徽的であった。

肝腫は劇症肝炎発症後一時縮小したが, その後再び 著明に増大し，助弓下 3 ないし 7 横指にわたる変化は 肝機能障害の経過と対応せず，むしろ糖疗病の調節不 良との関連が示惨された. 即ち, 肝炎発症前の $\mathrm{HbA}_{1}$ が 比較的低值であった時点では肝腫を認めず， $\mathrm{HbA}_{1}$ の 高値から血糖の調節不良が窥われた肝资発症時点では すでに助弓下 3 横指の肝腫を触知し, 以後肝機能異常 の回復した時点です血糖値異常とともに持続した。死 亡前食事摄取量の低下にもかかからず剖検肝は組織学
的に糖原に富み，また化学的定量による肝糖原含量は 正常域内6であったが対照例の約10倍の増加を認め, 肝腫は糖原の過剩蓄積によるものと推測された。因に 剖検時には胆汁うっ滞も著明ならっ血もみられず，星 細胞の鉄貣食も，生検標本では既に肝腫があったにも かかわらずこれを欠如したことから専ら輸血による鉄 沈着症であり，肝重量の増加に主因を演じたとは考え 難い. 血液透析例でみられる慢性らっ血性心不全の影 響》はあったとしても訮腫大の成因の一部に過ぎない と思われる。このよらな糖尿病に糖原蓄積を伴ら病態 は Brittle 型の糖尿病例にインスリン治療を行った際 にしばしばみられ゙)，クルコース濃度の上昇による糖 原の分解抑制之一過性のインスリン過㮃による糖原の 分解抑制並びに合成の促進によるとされている 炎例の訮においてはフォスフォリラーゼ活性は低下す ることが報告されておりの，併存した肝炎が糖原の蓄 積を助長したことも考劣られるが，一般的に障害肝で は糖原含有量の低下がみられるので，肝炎併存の影響 は明かでない，また，逆に糖原の分解過程になんらか の障害があると brittle 型糖尿病の経過をとることも 考えられるが，糖原の過剰蓄積を伴う不安定型糖尿病 例での肝糖原及びフォスフォリラーゼに異常はみられ ていない6.

一般に肝型 ALP 活性は肝内, 肝外の胆汁 5っ滞時 に著明な増加を示し，肝実質障害では $30 \mathrm{~K}-\mathrm{AU}$ 程度の 上昇に留まるので，黄㾝を伴う病態の鑑別に広く用い られている 上昇は，胆管の炎症並びに部分的あるいは不完全閉塞 のある場合にみられるが本症例ではそのような異常を 示寸所見がく, GOT, GPT, の活性と平行して变動 しており，肝害質障害との関連が示唆された。この变 化は, 正常域内での血清ビリルビン值の上昇傾向, 総 コレステロールの増加と胆汁うっ滞性 Slowmigrating HDL ${ }^{1,2}$ の出現をみたので, 胆汁ちっ滞の一 つの病態と考えるべきであろ5. Slow-migrating HDL は原発性胆汁性肝硬変 (PBC) の初期に高頻度に 出現するが，本症例に PBCの存在を疑わせる所見は 肝組織，血液検査ともになかった．本症例が軽症の胆 汁らっ滞であるとするにはALP 活性があまりにも高 值であり，著者らが提唱している胆汁うっ滞の特殊型 としての anicteric biliary enzyme elevation（無黄疸 珄胆道酳素上年症) ${ }^{11}$ が存在することを支持するるの として興味深い，活動性慢性肝炎と PBC の overlapping syndrome ${ }^{12)}$ と呼ばれているむのの中にこの病態 
に相当する症例がみられる，本症例におけるALPの 誘導機構として，胆汁酸以外に微小管の障害 ${ }^{13)}$ が考え られたが，抗体面からの検索引では否定的な結果で あった。糖尿病性の糖原蓄積例で ALP, GOT, GPT の単独上昇が報告されているので6)，高 ALP 血症は本 症に特徴的な所見である可能性もあり,ALP 活性の上 昇機序に関しては今後解明されるべき問題が多く残さ れている ${ }^{14,15)}$.

$$
\text { 結語 }
$$

血液透析中の糖尿病性堅症の 1 例にみられた著明な 肝腫之肝炎発症後の無黄㾝性高 ALP 血症が, 糖尿病 性の肝糖原蓄積量の増加と肝炎に付随した胆汁らっ滞 の特殊型としての無黄疸性胆道酵素上昇症によること を示唆する成績をえた。

謝辞 ALPの組織染色並びに肝糖原の測定において御 協力, 御指導を賜った上木房枝氏，岡山大学医学部第 1 外 科, 津下 宏博士，岡山済生会総合病院病理，浜家一雄博士， 倉敷中央病院内科，遠藤 浩博士，並びに抗細胞骨格抗体の 測定を担当して頂いたへルシンキ大学病理, Pekka kurki 博士に深謝致します。

\section{文献}

1) Watanabe $M$ : Lipoprotein abnormalities in cholestasis. II. Isolation, characterization and clinical evaluation of an additional cholestatic lipoprotein (Slow-migrating HDL). Acta Med Okayama 33 : 327-341, 1979

2) Koga S, Miyata $Y$, Ibayashi H : Plasma lipoproteins and apoproteins in primary biliary cirrhosis. Hepatology 5 : 286-292, 1985

3) Kurki $P$, Miettinen A, Salaspuro $M$, et al: Cytoskeleton antibodies in chronic active hepatitis, primary biliary cirrhosis, and alcoholic liver disease. Hepatology $3: 297-302,1983$

4) Kirkeby S, Moe D: Indoxyl methods for alkaline phosphatase. Cell Mol Biol 28: 261-265,
1982

5) Uchida T, Kronborg I, Peters RL : Acute viral hepatitis: Morphologic and functional correlations in human livers. Human Pathol 15: 267 $-277,1984$

6) Manderson WG, Mckiddie MT, Manners DJ, et al: Liver glycogen accumulation in unstable diabetes. Diabetes $17: 13-16,1968$

7) Pahl MV, Vaziri ND, Dure-Smith B, et al: Hepatobiliary pathology in hemodialysis patients : An autopsy study of 78 cases. Am J Gastroenterol 81 : 783-787, 1986

8) Stone BG, Van Thiel DH: Diabetes mellitus and the liver. Semin Liver Dis $5: 8-28,1985$

9) Kobayashi M: Studies of liver phosphorylase in hepatic injuries. I. Alteration in enzyme activity. Acta Med Okayama $32: 273-282,1978$

10）飯野四郎, 鈴木 宏, 織田敏次：血清アルカリホス ファターゼ (ALP) とそのアインェンザイム、日 本臨床 38:1350-1358, 1980

11) Taketa $K$, Izumi $M$, Yamamoto $H$, et al: Non-cholestatic increase in biliary enzyme activity, an isolated biochemical entity in cholestasis. Am J Gastroenterol 74 : 96, 1981

12) Shouval D, Levij IS, Eliakim $M$ : Chronic active hepatitis with cholestatic features. Am J Gastroenterol 72 : 542-550, 1979

13) Hatoff $\mathrm{DE}$, Katz RF, Ringard $\mathrm{AA}$ : Induction of hepatic alkaline phosphatase by colchicine: Role of cholestasis and bile acid. Proc Soc Expt Biol Med 173 : 227-230, 1983

14) Brensilver HL, Kaplan MM: Significance of elevated liver alkaline phosphatase in serum. Gastroenterology 68 : 1556-1562, 1975

15) Kaplan MM: Serum alkaline phosphatase -Another piece is added to the puzzle. Hepatology 6 : $526-528,1986$ 


\title{
A hemodialysis case of diabetic nephropathy with hepatomegaly related to unstable blood glucose level and with anicteric biliary enzyme elevation following acute hepatitis
}

\author{
Kazuhisa TAKETA*, Hiroyuki OHMORI**, Katsuo OGAWA**, Ken Yoshino***, \\ Seiichiro UEsUgi**, Akihiko OHMORI** and Kiyowo KosAKA**
}

An autopsy case of 36-year-old female patient with diabetic nephropathy placed under hemodialysis is described. The patient presented with a marked hepatomegaly, reaching a maximum of 7 fingers' breadth, associated with unstable blood glucose levels, fluctuating mostly between 100 and $1000 \mathrm{mg} / \mathrm{d} l$ under insulin treatment, and with an anicteric hyper-alkaline phosphatasemia associated with serum transaminase elevations during the course of chronic hepatitis of non- $A$, non- $B$ type following acute hepatic failure. The serum level of alkaline phosphatase (ALP) increased up to 77.8 $\mathrm{K}$-AU with other lines of cholestatic evidence, such as the elevation of serum total cholesterol or the appearance of Slow-migrating HDL, although the serum level of bilirubin did not exceed $1.0 \mathrm{mg} / \mathrm{d} l$. The results of histopathological studies revealed that the present case had a hepatic glycogenosis due to the unstable diabetes mellitus and an anicteric biliary enzyme elevation as an unusual type of cholestasis overlapping with chronic hepatitis.

* Health Research Center, Kagawa University (Kagawa)

** Shigei Medical Reseach Hospital (Okayama)

*** Shigei Hospital (Okayama) 